\title{
Ionic Mechanisms Underlying Autonomous Action Potential Generation in the Somata and Dendrites of GABAergic Substantia Nigra Pars Reticulata Neurons In Vitro
}

\author{
Jeremy F. Atherton and Mark D. Bevan \\ Department of Physiology, Feinberg School of Medicine, Northwestern University, Chicago, Illinois 60611
}

\begin{abstract}
Through their repetitive discharge, GABAergic neurons of the substantia nigra pars reticulata (SNr) tonically inhibit the target nuclei of the basal ganglia and the dopamine neurons of the midbrain. As the repetitive firing of SNr neurons persists in vitro, perforated, whole-cell and cell-attached patch-clamp recordings were made from rat brain slices to determine the mechanisms underlying this activity. The spontaneous activity of SNr neurons was not perturbed by the blockade of fast synaptic transmission, demonstrating that it was autonomous in nature. A subthreshold, slowly inactivating, voltage-dependent, tetrodotoxin (TTX)-sensitive $\mathrm{Na}^{+}$current and a TTX-insensitive inward current that was mediated in part by $\mathrm{Na}^{+}$were responsible for depolarization to action potential (AP) threshold. An apamin-sensitive spike afterhyperpolarization mediated by small-conductance $\mathrm{Ca}^{2+}$-dependent $\mathrm{K}^{+}$(SK) channels was critical for the precision of autonomous activity. SK channels were activated, in part, by $\mathrm{Ca}^{2+}$ flowing through $\omega$-conotoxin GVIA-sensitive, class 2.2 voltage-dependent $\mathrm{Ca}^{2+}$ channels. Although $\mathrm{Cs}^{+}$/ZD7288 (4-ethylphenylamino-1,2-dimethyl-6-methylaminopyrimidinium chloride)sensitive hyperpolarization-activated currents were also observed in $\mathrm{SNr}$ neurons, they were activated at voltages that were in general more hyperpolarized than those associated with autonomous activity. Simultaneous somatic and dendritic recordings revealed that autonomously generated APs were observed first at the soma before propagating into dendrites up to $120 \mu \mathrm{m}$ from the somatic recording site. Backpropagation of autonomously generated APs was reliable with no observable incidence of failure. Together, these data suggest that the resting inhibitory output of the basal ganglia relies, in large part, on the intrinsic firing properties of the neurons that convey this signal.
\end{abstract}

Key words: action potential; basal ganglia; pacemaker; sodium channel; Parkinson's disease; backpropagation

\section{Introduction}

The GABAergic neurons of the substantia nigra pars reticulata $(\mathrm{SNr})$ convey the final output signal of the basal ganglia to the thalamus and superior colliculus (Deniau et al., 1978; Bentivoglio et al., 1979). SNr neurons also innervate the substantia nigra pars compacta $(\mathrm{SNc})$ in which they influence the activity of dopaminergic neurons (Grace and Bunney, 1979; Tepper et al., 1995; Mailly et al., 2003). SNr neurons, like those of other extrastriatal basal ganglia nuclei, are tonically active (Yung et al., 1991; Bevan and Wilson, 1999; Chan et al., 2004). Brief changes in firing, often associated with movement (Sato and Hikosaka, 2002), therefore result in the disinhibition or further inhibition of neurons in the target nuclei of the basal ganglia (Delong, 1990). In addition, an altered pattern of $\mathrm{SNr}$ neuronal activity, from single-spike to burst firing, is characteristic of animal models of parkinsonism

Received April 14, 2005; revised July 8, 2005; accepted July 27, 2005.

This research was supported by National Institutes of Health-National Institute of Neurological Disorders and Stroke Grants NSO20702, NS041280, and NS047085. We are appreciative of Dr. Steve Kitai for his support and scientific contribution to this study.

Correspondence should be addressed to Dr. Mark D. Bevan, Department of Physiology, Feinberg School of Medicine, Northwestern University, 303 East Chicago Avenue, Chicago, IL 60611. E-mail: m-bevan@northwestern.edu. D0I:10.1523/JNEUROSCI.1475-05.2005

Copyright $\odot 2005$ Society for Neuroscience $\quad$ 0270-6474/05/258272-10\$15.00/0
(Wichmann et al., 1999; Tseng et al., 2000) and epilepsy (Deransart et al., 2003).

In anesthetized rats, the firing rate of SNr neurons is $\sim 25 \mathrm{~Hz}$ (Gernert et al., 2004; Windels and Kiyatkin, 2004). Lesion of the subthalamic nucleus (STN), the principal excitatory input to the $\mathrm{SNr}$ (Bevan et al., 1994), only results in a $20 \%$ reduction in $\mathrm{SNr}$ firing rate (Feger and Robledo, 1991; Zahr et al., 2004). Repetitive firing also persists in the heavily deafferented brain slice preparation (Nakanishi et al., 1987; Yung et al., 1991; Richards et al., 1997). Together, these observations suggest that the repetitive firing of SNr neurons may be generated, in part, autonomously. Our first objective was therefore to determine the relative contributions of intrinsic mechanisms and synaptic inputs to the activity of $\mathrm{SNr}$ neurons in vitro.

Several types of autonomously active neuron are depolarized to the threshold for action potential (AP) generation by a tetrodotoxin (TTX)-sensitive, slowly inactivating, voltage-dependent $\mathrm{Na}^{+}\left(\mathrm{Na}_{\mathrm{V}}\right)$ current (Bevan and Wilson, 1999; Raman and Bean, 1999; Taddese and Bean, 2002). This may also be supplemented by other inward currents, such as the hyperpolarization-activated current $\left(I_{\mathrm{h}}\right)$ (Maccaferri and McBain, 1996; Bennett et al., 2000; Chan et al., 2004) or a nonspecific cationic current (Raman et al., 2000; Jackson et al., 2004). In contrast, a membrane potential oscillation driven by $\mathrm{Ca}^{2+}$ currents underlies pacemaking in SNc 
dopamine neurons (Wilson and Callaway, 2000; Nedergaard, 2004). In several pacemakers, small-conductance $\mathrm{Ca}^{2+}$-activated potassium (SK) channels also play an important role in maintaining the precision of spiking (Bennett et al., 2000; Faber and Sah, 2002; Wolfart and Roeper, 2002; Hallworth et al., 2003). Having shown that the spontaneous discharge of $\mathrm{SNr}$ neurons in vitro is indeed driven by intrinsic properties, our second objective was to determine which of these ionic currents underlie activity.

Although spontaneous backpropagating APs have been reported in the dendrites of SNr neurons (Hausser et al., 1995), it is unclear whether these APs were generated by synaptic input or autonomous mechanisms. Our final objective was therefore to determine the somatodendritic site of origin of autonomously generated action potentials in SNr neurons and the reliability of AP propagation along their somatodendritic axis.

\section{Materials and Methods}

Slice preparation. Brain slices were prepared from 63 14- to 25-d-old male Sprague Dawley rats (Charles River Laboratories, Wilmington, MA). Experiments were performed in accordance with Society for Neuroscience, National Institutes of Health, and institutional policies. Animals were deeply anesthetized with a mixture of ketamine and xylazine before being perfused transcardially with $\sim 25 \mathrm{ml}$ of ice-cold modified artificial CSF (aCSF), which contained $230 \mathrm{~mm}$ sucrose, $2.5 \mathrm{~mm} \mathrm{KCl}, 1.25 \mathrm{~mm}$ $\mathrm{NaH}_{2} \mathrm{PO}_{4} \cdot \mathrm{H}_{2} \mathrm{O}, 0.5 \mathrm{~mm} \mathrm{CaCl} \cdot 2 \mathrm{H}_{2} \mathrm{O}, 10 \mathrm{~mm} \mathrm{MgSO}_{4} \cdot 7 \mathrm{H}_{2} \mathrm{O}, 10 \mathrm{~mm}$ glucose, and $26 \mathrm{~mm} \mathrm{NaHCO}$ and had been equilibrated with a gaseous mixture of $95 \% \mathrm{O}_{2}$ and $5 \% \mathrm{CO}_{2}$. The brain was rapidly removed, blocked, glued to the stage of a vibratome (Vibratome 3000 sectioning system; Vibratome Company, St. Louis, MO), and immersed in cooled equilibrated aCSF. Sagittal slices of $300 \mu \mathrm{m}$ thickness, which contained the $\mathrm{SNr}$, were cut and transferred to a holding chamber, in which they were submerged in aCSF containing $126 \mathrm{~mm} \mathrm{NaCl}, 2.5 \mathrm{~mm} \mathrm{KCl}, 1.25 \mathrm{~mm}$ $\mathrm{NaH}_{2} \mathrm{PO}_{4} \cdot \mathrm{H}_{2} \mathrm{O}, 2 \mathrm{~mm} \mathrm{CaCl} \cdot 2 \mathrm{H}_{2} \mathrm{O}, 2 \mathrm{~mm} \mathrm{MgSO}{ }_{4} \cdot 7 \mathrm{H}_{2} \mathrm{O}, 10 \mathrm{~mm}$ glucose, and $26 \mathrm{mM} \mathrm{NaHCO}_{3}$, equilibrated with $95 \% \mathrm{O}_{2} / 5 \% \mathrm{CO}_{2}$, and maintained at room temperature.

Drugs. All drugs were prepared as concentrated stock solutions and frozen. Drugs were then diluted in aCSF on the day of the experiment and bath applied. For experiments in which fast synaptic transmission was blocked, $50 \mu \mathrm{M}$ of the NMDA receptor antagonist D-(-)-2-amino-5phosphonopentanoic acid (APV) (Tocris Cookson, Ellisville, MO), 20 $\mu \mathrm{M}$ of the AMPA receptor antagonist 6,7-dinitroquinoxaline-2,3-dione (DNQX) (Tocris Cookson), and $20 \mu \mathrm{M}$ of the $\mathrm{GABA}_{\mathrm{A}}$ receptor antagonist 6-amino-3-(4-methoxyphenyl)-1 $(6 H)$-pyridazinebutanoic acid hydrobromide (GABAzine) (Tocris Cookson; SR 95531 hydrobromide) were continuously applied. TTX, apamin, and $\omega$-conotoxin GVIA were purchased from Sigma (St. Louis, MO); 4-ethylphenylamino-1,2dimethyl-6-methylaminopyrimidinium chloride (ZD7288) was purchased from Tocris Cookson.

Electrophysiology. Individual slices were transferred to a recording chamber in which they were perfused, at a rate of $2-3 \mathrm{ml} / \mathrm{min}$, with aCSF at $37^{\circ} \mathrm{C}$. Cell-attached, whole-cell, or gramicidin-based perforated patch recordings were made using borosilicate glass micropipettes (Warner Instruments, Hamden, CT) prepared with a P-97 Flaming-Brown micropipette puller (Sutter Instruments, Novato, CA). Pipettes for wholecell and perforated patch recordings were filled with a solution containing $135 \mathrm{~mm} \mathrm{~K}-\mathrm{MeSO}_{4}, 3.8 \mathrm{~mm} \mathrm{NaCl}, 1 \mathrm{~mm} \mathrm{MgCl} \cdot \cdot 6 \mathrm{H}_{2} \mathrm{O}, 10 \mathrm{~mm}$ HEPES, $0.1 \mathrm{~mm} \mathrm{Na}_{4}$ EGTA, $0.4 \mathrm{~mm} \mathrm{Na}_{3} \mathrm{GTP}$, and $2 \mathrm{~mm} \mathrm{Mg}_{1.5} \mathrm{ATP}$ titrated to a $\mathrm{pH}$ of 7.3 with $0.5 \mathrm{M} \mathrm{KOH}$ and diluted to an osmolarity of $290 \mathrm{mOsm}$. The resistance of pipettes filled with this solution was 3-7 M $\Omega$. For perforated recordings, gramicidin was added to the pipette solution at $\sim 20 \mu \mathrm{g} / \mathrm{ml}$. Pipettes for dendritic cell-attached recordings were filled with aCSF and had a resistance of 7-12 M $\Omega$. SNr cells were visualized in the slice with a $40 \times$ water-immersion objective (Axioscope; Zeiss, Oberkochen, Germany) and an infragradient contrast video microscopy system (Infrapatch Workstation; Luigs and Neumann, Ratingen, Germany). Experiments were executed and data were recorded using a personal computer running Clampex 9 (Axon Instruments, Union City, CA) connected to a
Multiclamp 200B amplifier (Axon Instruments) via a Digidata 1322A digitizer (Axon Instruments). Data were low-pass filtered at $10 \mathrm{kHz}$ and sampled at $50 \mathrm{kHz}$. Fast capacitive transients were compensated on-line; the calculated series resistance was compensated off-line. A liquid junction potential correction was subtracted off-line from all recordings ( $\mathrm{Ne}-$ her, 1992). For the recordings using normal aCSF in the whole-cell configuration, this junction potential was $9 \mathrm{mV}$ [experimentally measured junction potential, $8.7 \mathrm{mV}$; calculated junction potential (JPCalc; Barry, 1994), $9.2 \mathrm{mV}$ ]. In the perforated configuration, a second junction potential exists between the pipette solution and the neuronal cytoplasm. This junction potential cannot be directly measured, but it should disappear soon after the deliberate or accidental establishment of the wholecell configuration. We observed that there was indeed a depolarization of $\sim 5 \mathrm{mV}$ under these conditions. Therefore, using this depolarization as an estimate of the junction potential between the pipette and the cell, we estimated the sum of the two junction potentials in the perforated configuration to be $4 \mathrm{mV}$, and this correction was made off-line. For experiments in which $\mathrm{Na}^{+}$substitution was required, a HEPES-buffered aCSF was used. This contained $150 \mathrm{~mm} \mathrm{NaCl}, 2.5 \mathrm{~mm} \mathrm{KCl}, 10 \mathrm{~mm}$ HEPES, 10 mu glucose, $2 \mathrm{~mm} \mathrm{MgCl}_{2} \cdot 6 \mathrm{H}_{2} \mathrm{O}$, and $2 \mathrm{~mm} \mathrm{CaCl}_{2}$ titrated to $\mathrm{pH} 7.4$ with $\mathrm{NaOH}$ (resulting in a final $\mathrm{Na}^{+}$concentration of $\sim 154.5 \mathrm{~mm}$ ) and diluted to 300-310 mOsm. The low $\mathrm{Na}^{+}$solution was designed so that the $\mathrm{Na}^{+}$equilibrium potential would be $25 \mathrm{mV}$ : approximately halfway between the equilibrium potential in control conditions and the average resting potential of SNr cells in TTX. This was achieved by the substitution of $136.2 \mathrm{~mm} \mathrm{~N}$-methyl-D-glucamine (NMDG) for $\mathrm{NaCl}$, giving a final $\mathrm{Na}^{+}$concentration of $13.8 \mathrm{~mm}$. This solution was titrated with $\mathrm{HCl}$ to a $\mathrm{pH}$ of 7.4 and diluted to $300-310 \mathrm{mOsm}$. The calculated junction potentials for these HEPES-based solutions of $11 \mathrm{mV}$ (regular $\mathrm{Na}^{+}$) and $17 \mathrm{mV}$ (low $\mathrm{Na}^{+}$) were subtracted off-line.

Most voltage-clamp recordings were made in the whole-cell patch configuration, because this configuration is associated with a lower series resistance and therefore a more effective clamp of the membrane potential. However, in the whole-cell configuration, the replacement of the cytoplasmic contents with the pipette solution can disrupt intracellular $\mathrm{Ca}^{2+}$ dynamics and block intrinsic ion channels (Hallworth et al., 2003). Therefore, results acquired using whole-cell recordings were verified with perforated patch recordings. There were no gross differences in the data acquired using these two techniques, so, unless otherwise stated, results were collated for the purposes of statistical analysis.

Data analysis. Data were analyzed using the Clampfit 9 (Axon Instruments) and Origin 7 (Microcal Software, Northampton, MA) software packages. The firing characteristics of the cells [interspike interval, coefficient of variation (CV), and AP frequency and threshold] were calculated from trains of 101 spontaneous $\mathrm{APs}$. AP threshold $\left(\mathrm{AP}_{\text {th }}\right)$ was defined as the point at which the derivative of the membrane potential $(d V / d t)$ deviated from its mean during the interspike interval by greater than 2 SDs; this was detected using a custom programmed algorithm. Numerical data are presented as mean \pm SD, and the distributions of data are represented graphically using box plots. The central line of the box plots represents the median, the edges of the box show the interquartile range, and the edges of the "whiskers" show the full extent of the overall distribution. The mean of the data are also represented on the box plots with a small square. The use of small sample sizes precluded statistical determination of the distribution of the data; therefore, unless stated otherwise, the nonparametric Wilcoxon's signed-rank test was used for all statistical comparisons. An $\alpha$ value of 0.05 was used as the criterion for determining statistically significant differences.

\section{Results}

\section{GABAergic SNr neurons are spontaneously active}

Data collected from 95 cells were selected for additional analysis. Only cells that exhibited action potentials that crossed $0 \mathrm{mV}$ after junction potential correction were used in this study. Criteria for selection were also based on the electrophysiological comparisons of identified GABAergic and dopaminergic SNr neurons given by Yung et al. (1991) and Richards et al. (1997). Cells with properties that were closer to those described for dopamine neu- 
rons were excluded from the study. Specifically, putative $\mathrm{SNr}$ GABA neurons exhibited spontaneous action potentials in the single-spike mode with a width at threshold of $<2 \mathrm{~ms}$, they exhibited little or no "sag" in response to hyperpolarizing current injections, with no burst firing during release of this hyperpolarization, and they could maintain firing at frequencies above 50 $\mathrm{Hz}$ when driven by depolarizing current injections. Spontaneous activity recorded from 68 such neurons had a mean discharge rate of $10.78 \pm 6.00 \mathrm{~Hz}$.

Comparison of data acquired in the whole-cell and perforated configurations revealed no differences in the rate and pattern of autonomous activity. The firing rate of $\mathrm{SNr}$ neurons in the perforated configuration was $12.54 \pm 7.45 \mathrm{~Hz}$, whereas in the wholecell configuration, it was $9.30 \pm 3.98(n=31$ and 37 , respectively; $p=0.09$, Mann-Whitney $U$ test). The coefficient of variation was similarly unaffected (perforated patch CV, $0.06 \pm 0.03$; wholecell CV, $0.09 \pm 0.02 ; p=0.12$; Mann-Whitney $U$ test).

Synaptic inputs are not required for the generation of the spontaneous activity of $\mathrm{SNr}$ neurons in vitro

To test the hypothesis that the spontaneous firing seen in vitro is generated by a mechanism that is intrinsic to SNr neurons, APV, DNQX, and GABAzine were applied to spontaneously active $\mathrm{SNr}$ neurons in rat brain slices (Fig. 1). Under control conditions, nine $\mathrm{SNr}$ neurons that were recorded in the perforated patch configuration discharged at $11.35 \pm 3.27 \mathrm{~Hz}$ with a $\mathrm{CV}$ of $0.044 \pm 0.022$, and $\mathrm{AP}_{\text {th }}$ was $-44.28 \pm 6.20 \mathrm{mV}$. Bath application of $50 \mu \mathrm{M}$ APV, $20 \mu \mathrm{M}$ DNQX, and $20 \mu \mathrm{M}$ GABAzine did not affect these firing properties (firing frequency, $12.57 \pm 4.27 \mathrm{~Hz}, p=0.30 ; \mathrm{CV}, 0.041 \pm 0.012$, $\left.p=0.91 ; \mathrm{AP}_{\text {th }},-43.32 \pm 5.89 \mathrm{mV}, p=0.30\right)$.

The absence of effect of the blockade of fast synaptic transmission on the spontaneous activity of $\mathrm{SNr}$ neurons demonstrated that, in vitro, this activity is generated by intrinsic mechanisms, but, to ensure that only these intrinsic mechanisms were studied, all subsequent experiments were performed in the presence of APV, DNQX, and GABAzine.

\section{$\mathrm{Na}_{\mathrm{V}}$ channels are essential for the generation of rhythmic activity}

Unlike the dopaminergic neurons of the SNc (Shepard and Bunney, 1991; Kang and Kitai, 1993), SNr GABA neurons were simply slowed by hyperpolarization and exhibited a stable membrane potential when hyperpolarization was just sufficient to stop firing (Fig. $2 \mathrm{~A}$ ). We therefore hypothesized that autonomous rhythmic activity in SNr GABA neurons was dependent on APs. To test this hypothesis, AP generation was blocked by the application of the selective $\mathrm{Na}_{\mathrm{V}}$ channel blocker TTX $(1 \mu \mathrm{M})$. Figure $2 B 1-B 3$ shows an example of the action of $1 \mu \mathrm{M}$ TTX on an SNr GABA neuron. In both perforated patch $(n=4)$ and whole-cell $(n=11)$ experiments, the resting membrane potential after the complete abolition of AP firing was stable, with no remaining oscillation. Under these conditions, neither depolarizing currents nor the release from hyperpolarizing currents could induce oscillations in the membrane potential.

\section{The resting membrane potential is set by a TTX-insensitive inward current}

In the perforated patch configuration, $\mathrm{AP}_{\text {th }}$ was $-45.86 \pm 6.26$ $\mathrm{mV}$, and the membrane potential in the presence of TTX was $-43.64 \pm 3.92 \mathrm{mV}(n=4)$. In the whole-cell configuration, $\mathrm{AP}_{\text {th }}$ was $-47.12 \pm 4.36 \mathrm{mV}$, and the membrane potential in the pres-
A

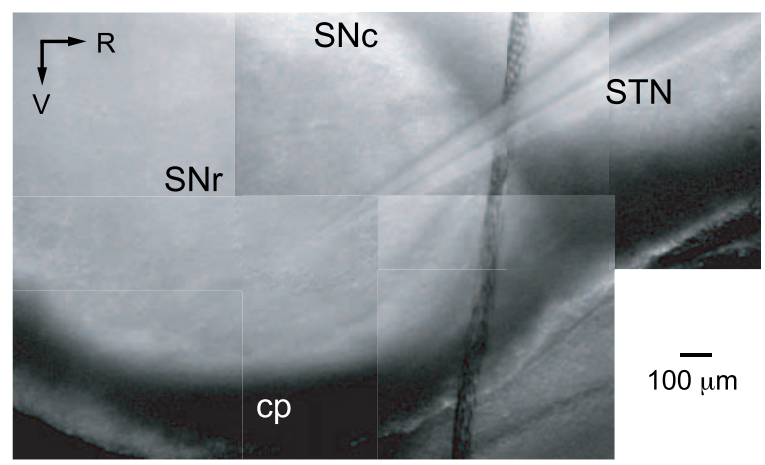

\section{B1}
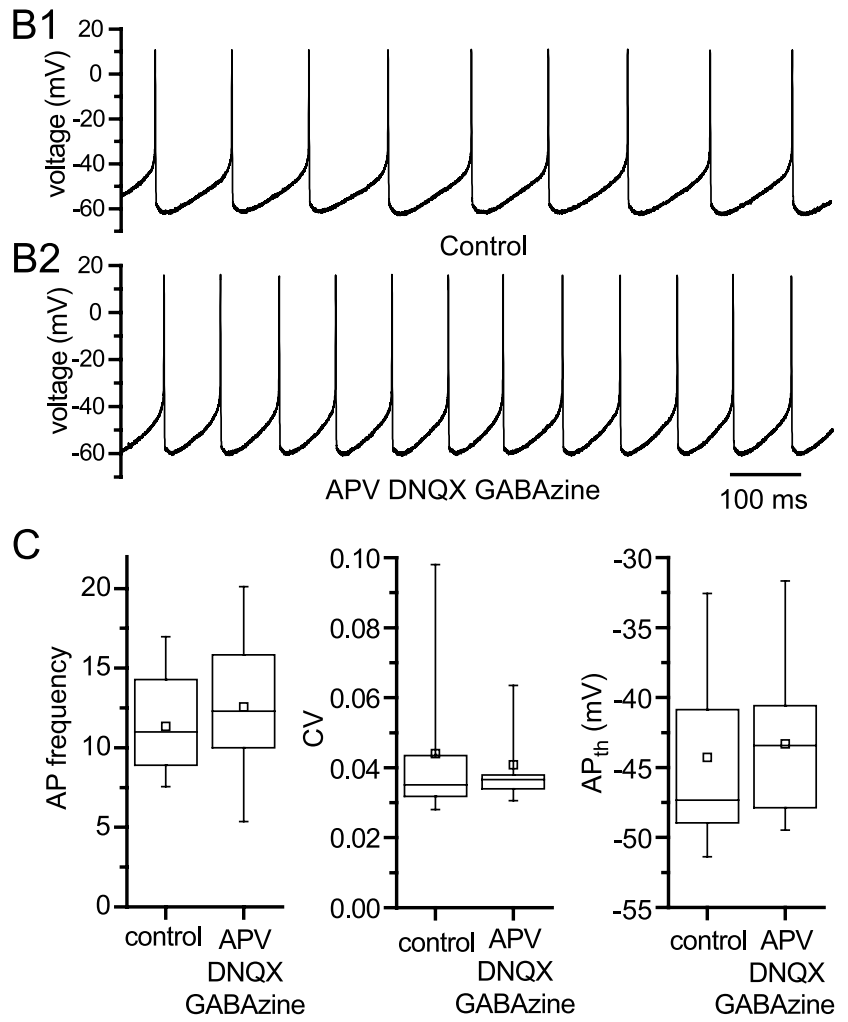

Figure 1. The spontaneous activity of $\mathrm{SNr}$ neurons in vitro is not generated by synaptic inputs. $A$, Photomicrograph showing a sagittal rat brain slice with a patch electrode positioned in the SNr. cp, Cerebral peduncle; R, rostral; V, ventral. $\boldsymbol{B}$, Perforated-patch current-clamp recordings from an $\mathrm{SNr}$ neuron. $\boldsymbol{B} 1$, Example of spontaneous activity recorded under control conditions. B2, Example showing autonomous firing from the same cell after the blockade of fast synaptic transmission by bath application of the antagonists APV, DNQX, and GABAzine. $C$, Box plots showing that the blockade of ionotropic glutamatergic and GABAergic synaptic transmission had no effect on the AP properties of nine SNr neurons. Application of APV, DNQX, and GABAzine had no statistically significant effects on AP frequency, $\mathrm{CV}_{\text {, or }} \mathrm{AP}_{\text {th. }}$.

ence of TTX was $-46.53 \pm 8.91 \mathrm{mV}(n=11)$. Together, the membrane potential in the presence of TTX was not significantly different from the previously measured $\mathrm{AP}_{\text {th }}$ (Fig. $\left.2 C, D\right)\left(\mathrm{AP}_{\text {th }}\right.$ in control conditions, $-46.79 \pm 4.72 \mathrm{mV}$; resting membrane potential in TTX, $-45.76 \pm 7.86 \mathrm{mV} ; n=15 ; p=0.52$ ). Figure $2 \mathrm{E}$ illustrates the difference between the resting membrane potential in TTX and $\mathrm{AP}_{\text {th }}$ plotted against the control firing frequency for each cell. For 7 of 15 cells, this difference was negative: the resting membrane potential was hyperpolarized to $\mathrm{AP}_{\text {th }}$, suggesting that TTX-sensitive currents were necessary to depolarize these cells to $\mathrm{AP}_{\text {th }}$. To test this hypothesis, voltage-clamp experiments were performed in which neurons were held at $-80 \mathrm{mV}$ and presented with a family of $1 \mathrm{~s}$ depolarizing steps (Fig. $2 \mathrm{~F} 1$ shows an example 


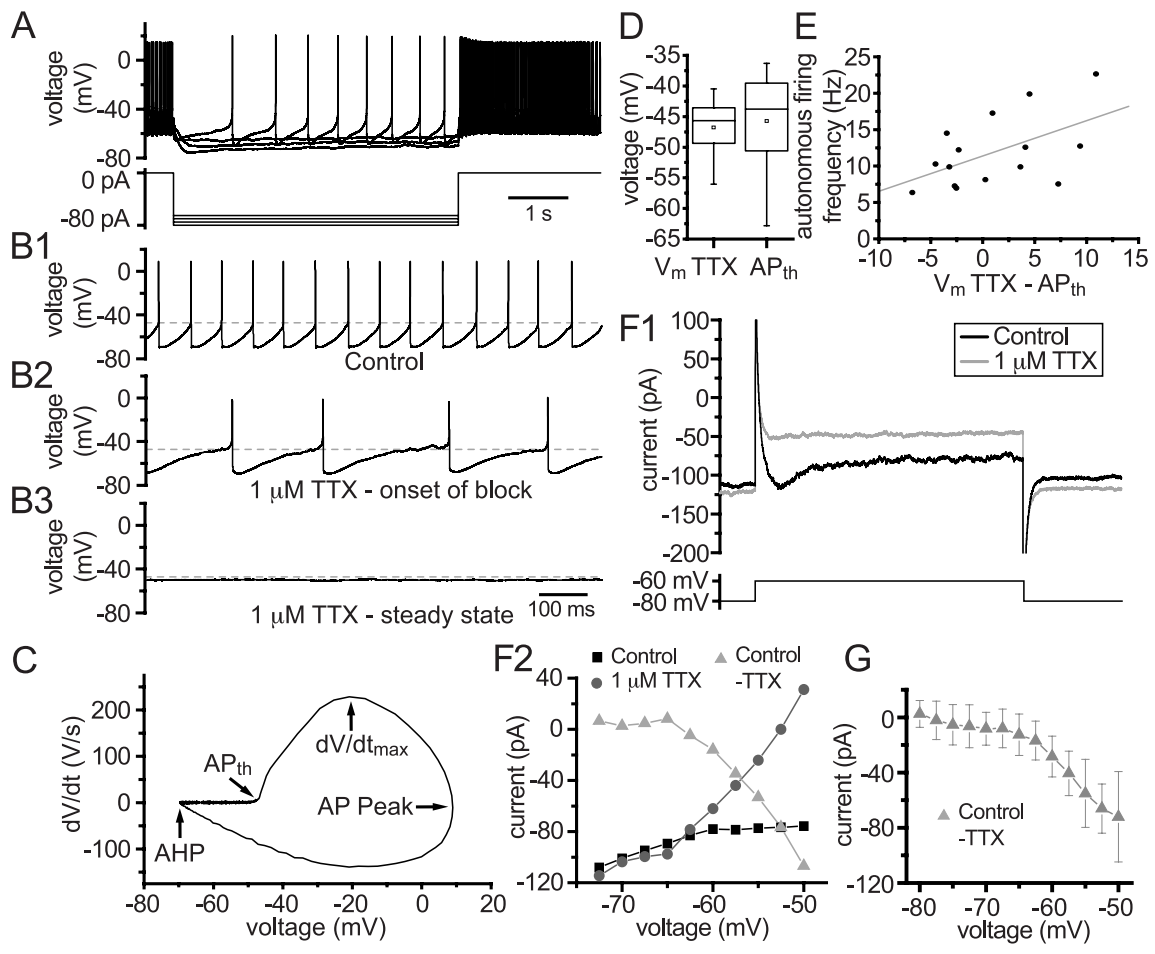

Figure 2. $\mathrm{Na}_{\mathrm{v}}$ channels are necessary for the generation of autonomous rhythmic activity in $\mathrm{SNr}$ neurons. A, Perforated-patch current-clamp recording from an $\mathrm{SNr}$ neuron showing the response to 5 s injections of hyperpolarizing current. Four sweeps are superimposed showing the hyperpolarizing step that was just insufficient to terminate firing $(-65 \mathrm{pA})$ and three additional steps $(-70,-75$, and $-80 \mathrm{pA})$ during which firing was prevented. $\boldsymbol{B}$, Rhythmic APs recorded in the whole-cell configuration (B1) were briefly disrupted (B2) and then completely terminated (B3) by bath application of $1 \mu \mathrm{M}$ TTX. C, The rate of change of membrane potential ( $d V / d t$ ) plotted against the membrane potential (phase plot). This phase plot is an average using all of the spikes shown in $B 1$. The inflection denoting $A P_{\text {th }}$ is indicated, as are the maximum rate of rise of the $A P\left(d V / d t_{\text {max }}\right.$, the peak of the $A P$, and the most hyperpolarized point of the AHP. D, Box plots comparing AP th before the application of TTX with the resting membrane potential in TTX $\left(V_{\mathrm{m}} \mathrm{TTX}\right)$ for 15 cells. $V_{\mathrm{m}}$ TTX was not significantly different from $\mathrm{AP}_{\mathrm{th}}$. $E$, The magnitude of the difference between $V_{\mathrm{m}}$ TTX and AP ${ }_{\mathrm{th}}$ is correlated with the frequency of autonomous firing before TTX application $(r=0.53 ; p<$ 0.05 , Student's $t$ test). $\boldsymbol{F 1}$, Whole-cell voltage-clamp recording showing the response of an $\mathrm{SNr}$ neuron to a $1 \mathrm{~s}$ depolarization to $-60 \mathrm{mV}$ from a holding potential of $-80 \mathrm{mV}$. The solid black line shows the response under control conditions, and the gray line shows the response of the same cell to the same protocol after the application of $1 \mu \mathrm{M}$ TTX. F2, Graph showing the steady-state (measured after $1 \mathrm{~s}$ ) current-voltage relationship over a range of test voltages for the cell shown in $\boldsymbol{F}$. Black squares represent the control data, gray circles the currents in the presence of $1 \mu \mathrm{M} \mathrm{TTX}$, and light gray triangles TTX subtracted currents. A TTX-sensitive current activated at voltages depolarized to approximately $-62.5 \mathrm{mV}$. G, Mean \pm SD steady-state currentvoltage relationship for nine cells showing the presence of a subthreshold TTX-sensitive inward current.

of one such step). $I-V$ curves plotted from the steady-state current at the end of each of these steps revealed a TTX-sensitive inward current that activated at voltages depolarized to approximately $-62.5 \mathrm{mV}$ (Fig. $2 \mathrm{~F} 2, \mathrm{G}$ ) and reached a peak of $-72.02 \pm$ $32.72 \mathrm{pA}(n=9)$, just below $\mathrm{AP}_{\mathrm{th}}(-50 \mathrm{mV})$.

However, 8 of 15 of the cells plotted in Figure $2 E$ had a resting potential that was depolarized to $\mathrm{AP}_{\mathrm{th}}$. Interestingly, the difference between the resting membrane potential in TTX and $\mathrm{AP}_{\text {th }}$ was correlated with the spontaneous firing frequency (Fig. $2 E$ ) $(r=0.53 ; p=0.04$, Student's $t$ test $)$. Also, during autonomous activity, the average peak of the afterhyperpolarization (AHP) seen after each AP was $-68.49 \pm 4.93 \mathrm{mV}, \sim 6 \mathrm{mV}$ hyperpolarized to the voltage range in which $\mathrm{Na}_{\mathrm{v}}$ channels are activated. As such, we hypothesized that an unidentified, TTX-insensitive current assisted the depolarization of GABAergic $\mathrm{SNr}$ neurons to $\mathrm{AP}_{\text {th }}$. To test this possibility, $\mathrm{SNr}$ neurons were recorded in current-clamp mode (in the whole-cell configuration) while the bathing solution was switched to a low $\mathrm{Na}^{+}$aCSF (Fig. 3A). Low $\mathrm{Na}^{+}{ }_{\text {aCSF }}$ abolished autonomous activity and produced a stable resting membrane potential with no subthreshold oscillation
(Fig. 3A2). This resting membrane potential was markedly more hyperpolarized than the resting potential that was seen previously in TTX $(-64.82 \pm 5.97 \mathrm{mV}, n=6$ vs $-45.76 \pm 7.86 \mathrm{mV}, n=15 ; p=0.011$, Mann-Whitney $U$ test). Returning to normal aCSF resulted in the partial restoration of autonomous action potential generation (Fig. 3A3). To compare the resting membrane potential of SNr neurons in TTX with the resting potential in low $\mathrm{Na}^{+} \mathrm{aCSF}$, experiments were performed in which 1 $\mu \mathrm{M}$ TTX was applied first in normal aCSF and then, subsequently, in low $\mathrm{Na}^{+}$aCSF. An example recording from such an experiment is shown in Figure 3B. In the perforated patch configuration, the resting membrane potential of SNr GABA neurons in TTX of $-41.38 \pm 2.67 \mathrm{mV}$ was hyperpolarized to $-62.58 \pm 2.06 \mathrm{mV}$ by the reduction of external $\mathrm{Na}^{+}(n=2)$. In whole-cell experiments the resting membrane potential in TTX of $-44.86 \pm 7.87$ $\mathrm{mV}$ was hyperpolarized to $-61.21 \pm 7.92$ $\mathrm{mV}$ by the reduction of external $\mathrm{Na}^{+}(n=$ 7). Overall, the resting membrane potential in TTX of SNr GABA neurons in this experiment was $-44.09 \pm 7.05 \mathrm{mV}$. Changing to low $\mathrm{Na}^{+}{ }_{\text {aCSF }}$ resulted in a significant hyperpolarization of the resting membrane potential to $-61.51 \pm 6.92 \mathrm{mV}$ (Fig. 3C,D) $(n=9 ; p=0.0039)$. Returning the bathing solution to normal aCSF reversed the hyperpolarization in all seven of the cells in which a wash was attempted. Voltage-clamp experiments in the presence of $1 \mu \mathrm{M}$ TTX (Fig. 3E,F) revealed a negative shift in the reversal potential of whole-cell current from $-56.28 \pm 1.46$ $\mathrm{mV}$ in control conditions to $-71.43 \pm 1.63$ $\mathrm{mV}$ in low $\mathrm{Na}^{+}(n=3)$. The discrepancy between the resting membrane potentials in TTX and the whole-cell reversal potential is likely to be a reflection of the greater disruption of intrinsic conductances caused by the more complete perfusion of neurons by the lower resistance electrodes used in the voltage-clamp experiments.

\section{Hyperpolarization-activated currents do not contribute to autonomous firing}

Immunohistochemical (Notomi and Shigemoto, 2004) and in situ hybridization (Monteggia et al., 2000; Santoro et al., 2000) studies have indicated that all known hyperpolarizationactivated cyclic nucleotide-gated (HCN) channel subunits, although primarily $\mathrm{HCN} 2$, are expressed within the SNr. This expression may be attributable, in part, to the presence of dopaminergic neurons within the $\mathrm{SNr}$, but there may also be some expression of functional HCN channels in the GABAergic neurons (Stanford and Lacey, 1996). We therefore hypothesized that $I_{\mathrm{h}}$ may be, in part, responsible for the depolarization toward $\mathrm{AP}_{\text {th }}$ that was observed in $\mathrm{SNr}$ neurons. This hypothesis was investigated by applying one of two relatively specific blockers of HCN channels, $50 \mu \mathrm{M}$ ZD7288 (Harris and Constanti, 1995) or 2 
$\mathrm{mm} \mathrm{CsCl}$, to $\mathrm{SNr}$ neurons. Figure 4 shows the effects of blockade of HCN channels on the AP frequency and pattern (as measured by $\mathrm{CV}$ ) of SNr neurons. In the perforated patch configuration, the control firing frequency of $12.86 \pm 4.78$ and $\mathrm{CV}$ of $0.031 \pm 0.004$ were unchanged by the application of $50 \mu \mathrm{M} \mathrm{ZD7288} \mathrm{(firing} \mathrm{fre-}$ quency in $\mathrm{ZD} 7288,11.33 \pm 4.23, n=6$, $p=0.31 ; \mathrm{CV}$ in ZD7288, $0.034 \pm 0.007$, $p=0.84)$. In separate whole-cell experiments, this result was replicated with the application of $2 \mathrm{~mm} \mathrm{CsCl}$ (control firing frequency, $10.33 \pm 3.82$; firing frequency in $\mathrm{CsCl}, 10.25 \pm 4.06, n=6, p=0.69$; control CV, $0.062 \pm 0.016$; $\mathrm{CV}$ in $\mathrm{CsCl}$, $0.048 \pm 0.017, p=0.16$ ).

Analysis of the response of $\mathrm{SNr}$ cells to hyperpolarizing current injections revealed that there was an increase in steadystate input resistance at voltages below approximately $-60 \mathrm{mV}$ when $2 \mathrm{~mm} \mathrm{CsCl}$ was present, resulting in a more profound hyperpolarization in response to the same current step (Fig. 4E,F). Voltage-clamp experiments were used to further investigate this change in input resistance. Using families of steps from a holding of -50 to $-110 \mathrm{mV}$, a slowly developing inward current was revealed at voltages negative to approximately $-70 \mathrm{mV}$ in all five neurons tested. This current could be blocked by the application of $2 \mathrm{~mm} \mathrm{CsCl}$ (Fig. 4G,H) and activated with an average rate constant of $581.75 \pm 297.74 \mathrm{~ms}$. This rate and voltage range of activation is consistent with subthalamic neurons (Do and Bean, 2003) in which HCN2 expression predominates (Notomi and Shigemoto, 2004). In the whole-cell configuration, it is possible that dialysis of the cell may alter the intracellular cAMP concentration, which could alter the voltage range of activation of $\mathrm{HCN}$ channels. Therefore, additional voltage-clamp experiments were performed in the perforated configuration. The inward current revealed in these experiments was similar to that seen in the wholecell experiments and was also sensitive to a selective $\mathrm{HCN}$ channel blocker, in this case $20 \mu \mathrm{M}$ ZD7288 (supplemental Fig. 1, available at www.jneurosci.org as supplemental material). Together, these data show that, although $I_{\mathrm{h}}$ is present in SNr neurons, it is not involved in the generation of the autonomous activity because the voltage range at which it is activated is more hyperpolarized than that traversed during autonomous activity.

\section{Apamin-sensitive channels are critical for precise, rhythmic autonomous activity}

In several types of basal ganglia neuron, an apamin-sensitive outward current mediated by SK channels is responsible for the socalled medium AHP, which has been shown to be important for the frequency and precision of autonomous activity (Shepard and Bunney, 1991; Wolfart et al., 2001; Wolfart and Roeper, 2002; Hallworth et al., 2003; Wilson et al., 2004). In situ hybridization has also shown that SK channels are strongly expressed in putative SNr GABA neurons (Stocker and Pedarzani, 2000; Tacconi et al., 2001). Indeed, in our recordings from GABAergic $\mathrm{SNr}$ neurons, the hyperpolarization after each AP often consisted of two distinct elements (Fig. 3A1): a rapid hyperpolarization followed by a slower hyperpolarization similar to the medium AHP that is blocked by apamin in other neuronal types (Bond et al., 2004; Villalobos et al., 2004). Therefore, we hypothesized that apamin-sensitive SK channels also play an important role in the maintenance of the frequency and precision of single-spike firing in these neurons. Figure $5 A 1-A 3$ summarizes the range of effects that were observed during the application of $100 \mathrm{~nm}$ apamin to SNr GABA neurons. Apamin application resulted in the disappearance of the medium component of the AHP (Fig. $5 C$ ), with little apparent effect on the rapid component of AP repolarization (Fig. 5D). In one-third (4 of 12, 1 perforated patch and 3 whole-cell) of the neurons tested, the loss of the AHP was followed within $10 \mathrm{~min}$ by a strong depolarization of the cell that resulted in the cessation of firing (as shown in the example in Fig. $5 A 3)$. In these cases, firing could often be restored by the injection of hyperpolarizing current (data not shown). Of the remaining neurons, the control firing rate in perforated patch recordings $(n=4)$ was $14.30 \pm 7.75 \mathrm{~Hz}$, and the firing rate in apamin was $18.11 \pm 10.72 \mathrm{~Hz}$. The control CV in perforated patch was $0.050 \pm 0.013$, and the $\mathrm{CV}$ in apamin was $0.150 \pm 0.066$. The $\mathrm{AP}_{\text {th }}$ in control conditions was $-43.13 \pm 4.82 \mathrm{mV}$, and in apamin it was $-39.85 \pm 5.12 \mathrm{mV}$. The control firing rate in whole-cell recordings $(n=4)$ was $10.86 \pm 4.31$, and the firing rate in apamin was $15.53 \pm 9.61 \mathrm{~Hz}$. The control CV in whole-cell recordings was $0.059 \pm 0.028$, and the CV in apamin was $0.174 \pm 0.001$. The $\mathrm{AP}_{\text {th }}$ in control conditions was $-46.84 \pm 4.45 \mathrm{mV}$, and in apamin it was $-45.22 \pm 4.80 \mathrm{mV}$. Overall, these eight cells showed a small but nonsignificant increase in firing rate (Fig. 5E) (control, $12.59 \pm$ 
A
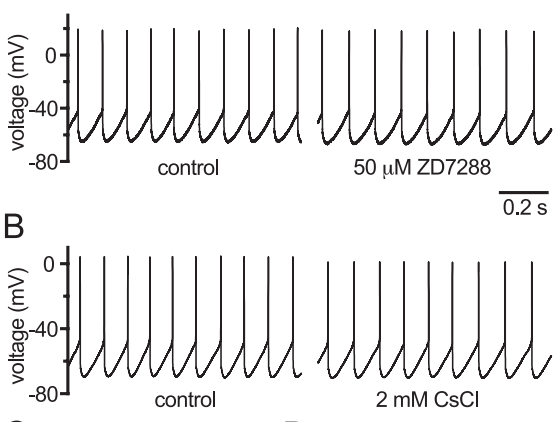

C

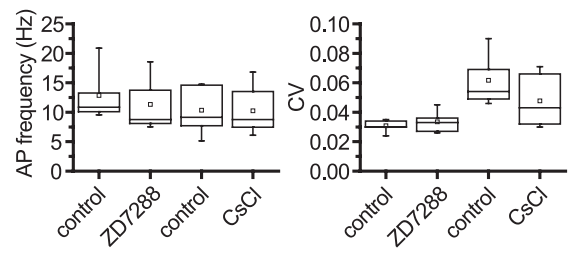

E1
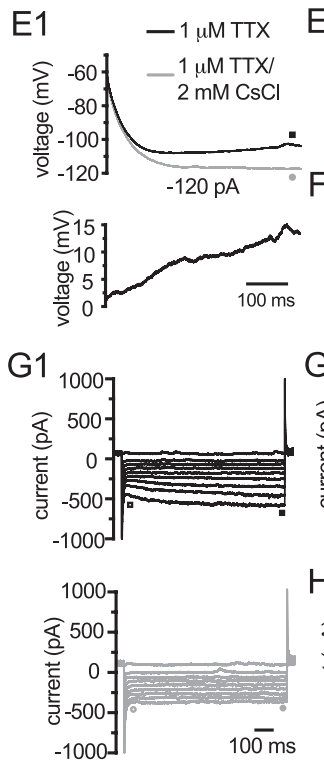
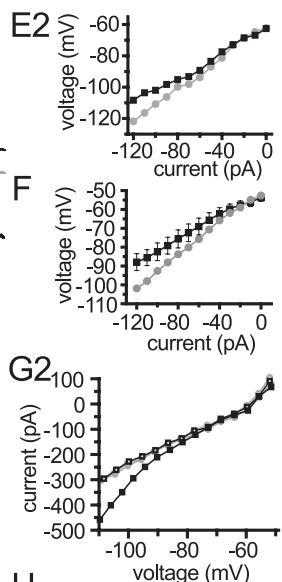

$\mathrm{H}$

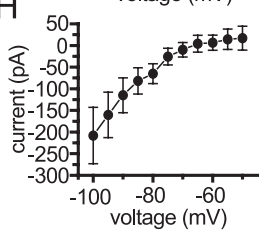

Figure 4. HCN channels do not contribute to autonomous firing. $A$, Autonomous activity of an $\mathrm{SNr}$ neuron recorded in the perforated patch configuration before and during bath application of $50 \mu \mathrm{m}$ ZD7288. B. Autonomous activity of an SNr neuron recorded in the whole-cell configuration before and during bath application of $2 \mathrm{~mm} \mathrm{CsCl.C,D,Box} \mathrm{plots} \mathrm{showing} \mathrm{the} \mathrm{effects} \mathrm{of}$ ZD7288 and CsCl on AP frequency ( $C$ and CV (D). E1, Response of an SNr neuron to a -120 pA hyperpolarizing current pulse before (black) and after (gray) the application of $2 \mathrm{~mm} \mathrm{CsCl}$. The bottom panel shows a subtraction of these two traces revealing that the increased hyperpolarization in response to $-120 \mathrm{pA}$ in the presence of CSCI develops slowly over the duration of the pulse. E2, Steady-state I-V relationship for the cell shown in $A$ in the presence of $1 \mu \mathrm{m}$ TTX (black) or $1 \mu \mathrm{m}$ TTX and $2 \mathrm{~mm} \mathrm{CsCI} \mathrm{(gray).} F$, Steady state $I-V$ relationship for six cells revealing an increase in input resistance during $\mathrm{CsCl}$ application at voltages below approximately $-65 \mathrm{mV}$, as evidenced by the greater degree of hyperpolarization elicited by the same current steps. G1, Example of voltageclamp recordings, in the presence of $1 \mu \mathrm{M}$ TTX, showing a family of currents evoked by $1 \mathrm{~s}$ hyperpolarizing steps from a holding potential of $-50 \mathrm{mV}$. At the most hyperpolarized potentials, a slowly activating inward current was evoked that could be blocked by $2 \mathrm{~mm} \mathrm{CsCl.} \mathrm{G2,} \mathrm{Example} \mathrm{I-V} \mathrm{plots} \mathrm{of} \mathrm{the} \mathrm{early} \mathrm{(open} \mathrm{symbols)} \mathrm{and} \mathrm{late} \mathrm{(filled} \mathrm{symbols)} \mathrm{currents} \mathrm{recorded} \mathrm{from} \mathrm{the} \mathrm{cell} \mathrm{shown} \mathrm{in}$ G1. The early control currents (open black squares) overlay almost exactly with both the early (open gray circles) and late (filled gray circles) currents measured in CsCl. $\boldsymbol{H}$, Mean CsCl-subtracted steady-state I-V plot for five cells.

\section{- Control $100 \mathrm{nM}$ Apamin}

A1

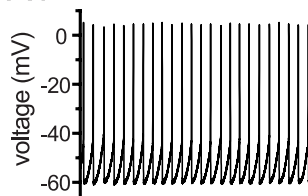

C

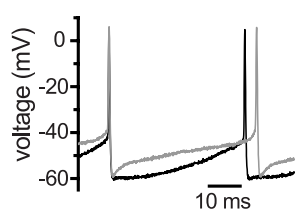

D

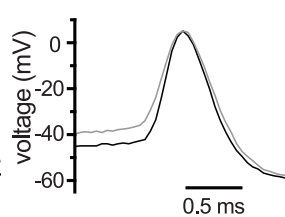

A2

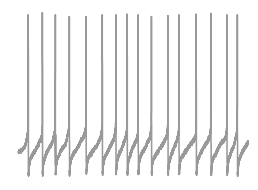$$
0.5 \mathrm{~ms}
$$
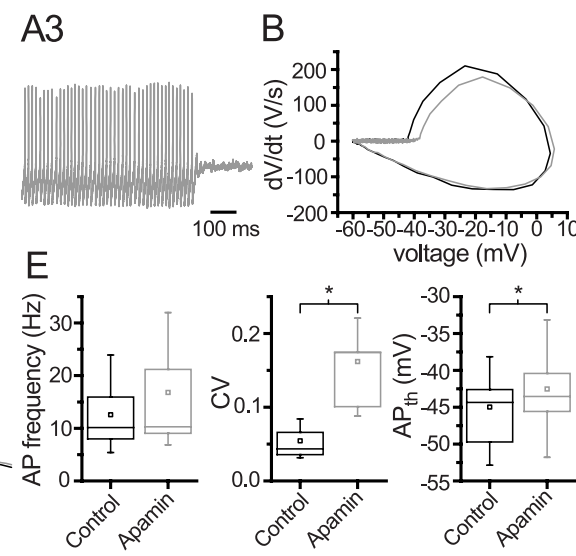

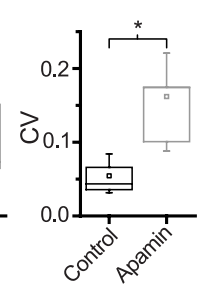
voltage $(\mathrm{mV})$

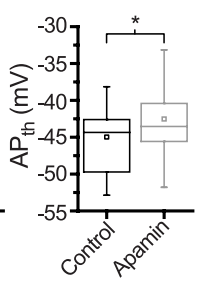

Figure 5. Blockade of SK channels with apamin reduces the precision and modifies the frequency of firing of SNr neurons by reducing the single spike AHP. $\boldsymbol{A}$, Whole-cell current-clamp recording from an $\mathrm{SNr}$ neuron before $(\boldsymbol{A 1})$ and during $(\boldsymbol{A 2})$ the application of $100 \mathrm{~nm}$ apamin. $\boldsymbol{A} 3$, In this neuron, and $\sim 40 \%$ of neurons tested, apamin eventually resulted in the cessation of AP firing through depolarization block. $B, A$ comparison of phase plots from this neuron before and during the application of apamin revealed that $A P_{t h}$ and the maximal rate of rise of the $A P$ were increased by apamin, presumably attributable to the decreased availability of $\mathrm{Na}_{\mathrm{v}}$ channels that accompanied depolarization. C, $\boldsymbol{D}$, Expanded plots of firing from $\boldsymbol{A} \mathbf{1}$ and $\boldsymbol{A} \mathbf{2}$ illustrate the action of apamin on AP morphology and spike afterhyperpolarization. $\boldsymbol{E}$, Box plots comparing the firing properties of eight SNr neurons before and during the application of apamin.

$6.09 \mathrm{~Hz}$; apamin, $16.82 \pm 9.53 \mathrm{~Hz} ; p=0.20)$, a disturbed firing pattern (Fig. $5 E$ ) (control $\mathrm{CV}, 0.054 \pm 0.021$; apamin CV, $0.162 \pm$ $0.045 ; p=0.0078)$, and a depolarized $\mathrm{AP}_{\text {th }}$ (Fig. 5B,D,E) (control AP th $_{\text {th }}-44.98 \pm 4.73$ $\mathrm{mV}$; apamin $\mathrm{AP}_{\mathrm{th}},-42.53 \pm 5.41 \mathrm{mV} ; p=$ $0.016)$.

\section{Class 2.2 voltage-dependent $\mathrm{Ca}^{2+}$ $\left(\mathrm{Ca}_{\mathrm{v}} 2.2\right)$ channels regulate the} frequency and precision of autonomous activity through their functional coupling to SK channels

The strong effects of SK channel blockade with apamin are suggestive that voltagedependent $\mathrm{Ca}^{2+}$ channels are active during autonomous spiking. Voltagedependent $\mathrm{Ca}^{2+}$ currents in SNr GABA neurons have not been extensively characterized. Evidence from immunohistochemical studies points to a strong expression of $\mathrm{Ca}_{\mathrm{V}} 2.2$ (N-type) channels in dendrites and a weaker expression in the cell bodies of $\mathrm{SNr}$ neurons (Westenbroek et al., 1992), whereas there is little evidence for the expression of other voltagedependent $\mathrm{Ca}^{2+}$ channel subtypes in these cells. Therefore, we hypothesized that activation of SK channels is coupled to the entry of $\mathrm{Ca}^{2+}$ ions into $\mathrm{SNr}$ neurons through $\mathrm{Ca}_{\mathrm{v}} 2.2$ channels. Figure 6 shows the effects of the blockade of $\mathrm{Ca}_{\mathrm{V}} 2.2$ with 1 $\mu \mathrm{M} \omega$-conotoxin GVIA on SNr GABA neurons. As for apamin, $\omega$-conotoxin GVIA application resulted in the loss of the medium component of the AHP (Fig. $6 C, D)$. In the perforated patch configuration $(n=3)$, the firing rate in control conditions was $11.60 \pm 4.38 \mathrm{~Hz}$, and the $\mathrm{CV}$ was $0.073 \pm 0.014$; the firing rate in $\omega$-conotoxin GVIA was $15.39 \pm 5.31 \mathrm{~Hz}$, and the CV $0.113 \pm 0.029$. In whole-cell recordings $(n=3)$, the firing rate in control conditions was $10.84 \pm 5.27 \mathrm{~Hz}$, and the $C V$ was $0.088 \pm 0.042$; the firing rate in $\omega$-conotoxin GVIA was $12.55 \pm 4.92 \mathrm{~Hz}$, and the CV $0.166 \pm 0.115$. Overall, there was a statistically significant increase in the firing rate (Fig. $6 E$ ) (control, $11.22 \pm 4.35$ $\mathrm{Hz}$; $\omega$-conotoxin GVIA, $13.97 \pm 4.84 \mathrm{~Hz}$; $n=6 ; p=0.031)$ and a disruption in the firing pattern (Fig. 6E) (control CV, $0.080 \pm 0.029 ; \omega$-conotoxin GVIA CV, $0.140 \pm 0.080 ; p=0.031)$. Although the precision of autonomous activity was significantly reduced after the blockade of $\mathrm{Ca}_{\mathrm{v}} 2.2$ channels, the disruption was not as profound as that observed after the blockade of SK channels. Furthermore, the frequency of autonomous activity was significantly increased by the blockade of $\mathrm{Ca}_{\mathrm{v}} 2.2$ channels in contrast to the effects observed after apamin applica- 
tion. Although supporting the hypothesis that $\mathrm{Ca}^{2+}$ flowing through $\mathrm{Ca}_{\mathrm{v}} 2.2$ channels is coupled to the activation SK channels, these data leave open the possibility that other $\mathrm{Ca}^{2+}$ sources may also be important.

\section{Autonomously generated APs reliably backpropagate along the dendrites of SNr neurons}

It has been reported previously (Hausser et al., 1995) that APs observed at the soma of SNr GABA neurons backpropagate into their dendrites. Thus, single, spontaneous, or driven APs (elicited by somatic or dendritic depolarization) backpropagated up to $\sim 100 \mu \mathrm{m}$ from the soma. However, this study did not distinguish between spontaneous APs that were generated by autonomous mechanisms or spontaneous synaptic inputs. Similarly, the reliability of backpropagation of continuously, autonomously generated APs into the dendrites of SNr GABA neurons was not studied. To address these issues further, we used dual somatic and dendritic cell-attached recordings of $\mathrm{SNr}$ GABA neurons in the presence of APV, DNQX, and GABAzine (Fig. 7). These recordings revealed an autonomous rhythmic discharge in both the somata and dendrites of all $11 \mathrm{SNr}$ GABA neurons tested (Fig. 7). Analysis of the relative timing of the peaks of action currents demonstrated that, in 10 of 11 of these cases, the peak of the dendritic AP closely followed the peak of the somatic AP (Fig. $7 A 3, B)$. The delay of the dendritic AP relative to the somatic AP was also well correlated with the distance of the dendritic electrode from the somatic recording site (Fig. 7C) $(r=0.76 ; p=0.018$, Student's $t$ test), suggesting that the site of AP generation was closer to the soma than the dendritic recording site. In the 10 of 11 neurons in which the AP was first recorded at the soma, each autonomously generated AP faithfully propagated to the dendritic recording site. Together, these data suggest that, in SNr GABA neurons, autonomously generated APs are generated close to the soma and then propagate with high reliability into the dendritic tree.

\section{Discussion}

\section{Intrinsic inward currents drive spontaneous firing}

Intrinsic currents were responsible for the spontaneous discharge of rat $\mathrm{SNr}$ neurons in vitro because this activity persisted in the absence of fast synaptic transmission. In an autonomously active neuron, a net inward current is required for depolarization to $\mathrm{AP}_{\text {th }}$ because $\mathrm{K}^{+}$ channels and the $\mathrm{Na}^{+} / \mathrm{K}^{+}$pump combine to hyperpolarize the neuron toward the equilibrium potential for $\mathrm{K}^{+}\left(E_{\mathrm{K}}\right)$. Indeed, the threshold at which $\mathrm{Na}_{\mathrm{V}}$ currents were regenerative and triggered APs in $\mathrm{SNr}$ neurons was approximately $-45 \mathrm{mV}$, which was over $50 \mathrm{mV}$ positive to $E_{\mathrm{K}}$.
A2

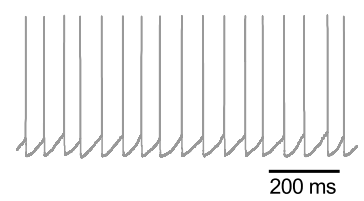

B

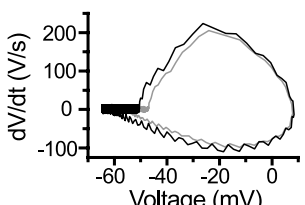

c

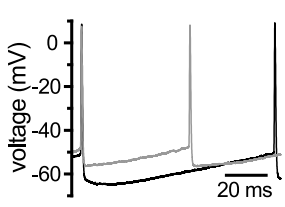

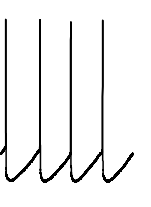

D
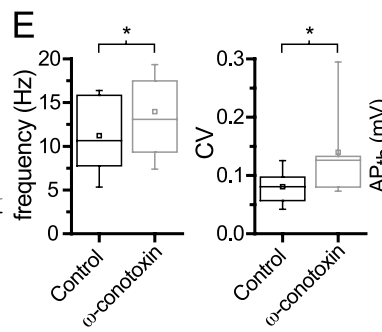

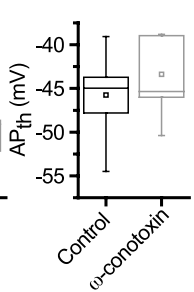

Figure 6. Blockade of voltage-dependent $C a_{v} 2.2$ channels reduces single-spike afterhyperpolarization. $\boldsymbol{A}$, Perforated-patch clamp recording from an SNr neuron before $(\boldsymbol{A} 1)$ and during $(\boldsymbol{A 2})$ the application of $1 \mu \mathrm{m} \boldsymbol{\omega}$-conotoxin GVIA. $\boldsymbol{B}, A$ comparison of phase plots constructed from APs before and during conotoxin application. Note the elevated $A P_{\text {th }}$ and reduced maximal rate of Note the elevated $A P_{\text {th }}$ and the reduction in single-spike $A H P$ after the blockade of $\mathrm{Ca}_{\mathrm{v}} 2.2$ channels. $\boldsymbol{E}$, Box plots comparing the firing properties of six SNr neurons before and during the application of $\omega$-conotoxin GVIA. Although the precision of autonomous after the blockade of SK channels. Furthermore, the frequency of autonomous activity was significantly increased by the blockade
A1

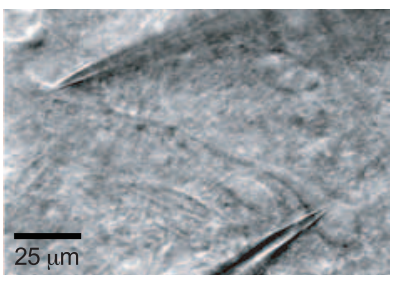

A3

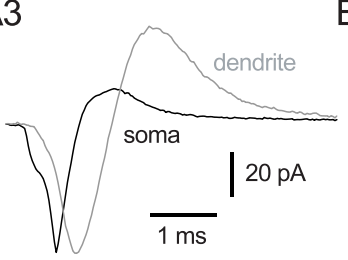

A2

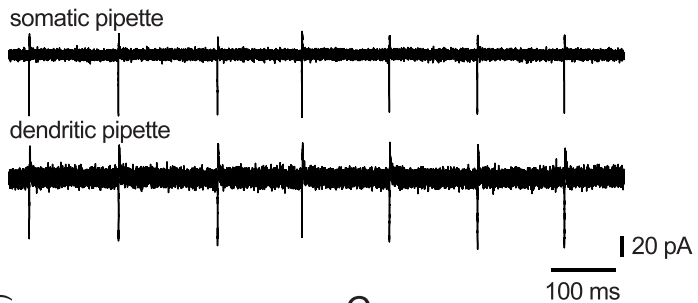

B

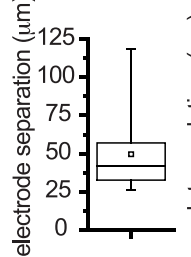

$\mathrm{C}$
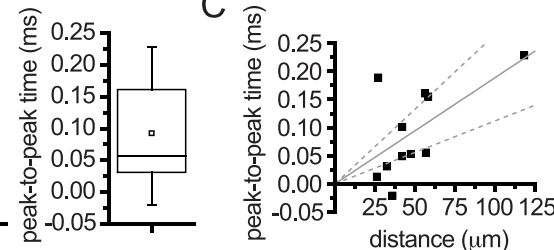

Figure 7. Autonomously generated APs propagate into the dendrites of SNr neurons. A1, Photomicrograph showing an infragradient-contrast image of an SNr neuron with patch pipettes on its soma and a dendrite. $\mathbf{A 2}$, Cell-attached voltage-clamp recordings (holding potential, $0 \mathrm{mV}$ ) from the soma and dendrite of the neuron shown in $\boldsymbol{A 1}$. Note the rhythmic, autonomous generation of action currents in the soma and dendrite. A3, Overlay of the average of 100 action currents recorded in the soma (black) and dendrite (gray). The somatic action current clearly precedes the dendritic action current. $\boldsymbol{B}$, Box plots showing the range of soma-to-dendrite recording distances and peak-to-peak times for action currents in somata and dendrites. $\boldsymbol{C}$, Plot of the relationship of the distance between the somatic and dendritic recording sites and the peak-to-peak time of action currents in the soma and dendrite. The dotted lines represent the $95 \%$ confidence interval of the linear fit. As predicted, the delay between the action currents measured in the soma and the dendrite increases with the distance between the recording sites.

Many types of neuron possess a slowly inactivating $\mathrm{Na}_{\mathrm{V}}$ current in the subthreshold voltage range. Often called the persistent $\mathrm{Na}^{+}$current $\left(I_{\mathrm{NaP}}\right)$, this TTX-sensitive current has also been found to support the spontaneous activity of principal neurons in, for example, the STN (Bevan and Wilson, 1999; Beurrier et al., 2000; Do and Bean, 2003), tuberomammillary nucleus (Taddese and Bean, 2002), and cerebellum (Raman and Bean, 1999). Indeed, voltage-clamp experiments in $\mathrm{SNr}$ neurons revealed the presence of a slowly inactivating TTX-sensitive inward current that activated at voltages more depolarized than approximately 
$-62.5 \mathrm{mV}$. However, this value is often up to $7.5 \mathrm{mV}$ more depolarized than the foot of the interspike interval. In addition, the resting membrane potential of SNr neurons after TTX application was close to $\mathrm{AP}_{\text {th }}$. Together, these data indicate that a TTXsensitive $\mathrm{Na}^{+}$current, including $I_{\mathrm{NaP}}$, is unlikely to be the only inward current that depolarizes $\mathrm{SNr}$ neurons to $\mathrm{AP}_{\text {th }}$. We also noted that the difference between $\mathrm{AP}_{\text {th }}$ and the resting membrane potential in TTX was correlated with the firing frequency of $\mathrm{SNr}$ neurons, suggesting that tonic depolarization set by a TTXinsensitive inward current greatly influences the autonomous firing rate.

Neurons express additional voltage-dependent channels that are activated in the subthreshold voltage range, mediate inward currents, and thus assist depolarization toward $\mathrm{AP}_{\text {th }}$. One such inward current is $I_{\mathrm{h}}$ : examples of neurons in which both $I_{\mathrm{NaP}}$ and $I_{\mathrm{h}}$ have been found to contribute to the generation of spontaneous activity include hippocampal stratum oriens-alveus interneurons (Maccaferri and McBain, 1996), striatal cholinergic interneurons (Bennett et al., 2000; Wilson, 2005), and neurons in the external globus pallidus (Chan et al., 2004). In each case, the blockade of HCN channels with $\mathrm{Cs}^{+}$or ZD7288 slowed but did not prevent spontaneous firing. However, despite the strong expression of HCN2 mRNA in the SNr (Notomi and Shigemoto, 2004), the spontaneous discharge of SNr GABA neurons was unaffected by the application of ZD7288 or Cs ${ }^{+}$. Moreover, although analysis of current-clamp and voltage-clamp recordings revealed activation of $I_{\mathrm{h}}$ at voltages negative to $-70 \mathrm{mV}$, this value was typically more hyperpolarized than the voltage range traversed during the interspike interval. Thus, under resting conditions, $I_{\mathrm{h}}$ does not contribute to pacemaking in SNr GABAergic neurons.

For each of the neuronal types described above, autonomous activity is dependent on APs: abolition of APs with hyperpolarization or TTX results in a stable membrane potential. There are, however, other cell types in which this is not the case: in these cells, after spiking is abolished, a membrane potential oscillation remains. An example of this are the dopaminergic cells of the SNc (Shepard and Bunney, 1991; Kang and Kitai, 1993). The depolarizing phase of the oscillation in these cells is primarily attributable to the activation at subthreshold potentials of nimodipinesensitive $\mathrm{Ca}_{\mathrm{V}} 1.2-1.3$ (L-type) channels (Nedergaard et al., 1993; Mercuri et al., 1994; Durante et al., 2004). Similar subthreshold nimodipine-sensitive oscillations have been observed in dorsomedial suprachiasmatic nucleus neurons (Pennartz et al., 2002; Jackson et al., 2004). Conversely, in inferior olive neurons (Llinas and Yarom, 1981a,b), lateral habenula nucleus neurons (Wilcox et al., 1988), and thalamocortical relay neurons (McCormick and Pape, 1990), $\mathrm{Ca}_{\mathrm{V}} 3$ channels underlie a T-type current that is involved in the generation of subthreshold membrane potential oscillations. Our experiments revealed no evidence for such $\mathrm{Ca}^{2+}$-dependent oscillations in SNr GABA neurons because, when spiking was abolished, either with hyperpolarizing current injection or through the application of TTX, subthreshold membrane potential oscillations were not observed.

A final, and less well understood, inward current that is found to be responsible for subthreshold depolarization in some cells is a voltage-independent and TTX-insensitive "background" conductance. Neurons of the cerebellar nuclei were found to have a depolarized resting membrane potential in the presence of TTX that was not hyperpolarized by the application of $\mathrm{CsCl}$ or the replacement of $\mathrm{Ca}^{2+}$ with $\mathrm{Co}^{2+}$ (Raman et al., 2000). Only replacement of $\mathrm{Na}^{+}$with NMDG led to a significant hyperpolarization of the membrane potential. The authors concluded that the neurons of the cerebellar nuclei expressed a tonic cationic flux, carried in part by $\mathrm{Na}^{+}$ions, which they compared with the nonselective background cation currents of cardiac cells. Similar TTX-insensitive background $\mathrm{Na}^{+}$currents have been reported in rat locus ceruleus neurons (Alreja and Aghajanian, 1993), preBötzinger complex neurons (Pena and Ramirez, 2004), and dorsomedial suprachiasmatic nucleus neurons (Jackson et al., 2004). The similarity of our findings with those in the cerebellar nuclei is striking. SNr neurons rested at a relatively depolarized membrane potential when exposed to TTX, and their spontaneous firing was unaffected by blockade of HCN channels. Recording in a reduced $\mathrm{Na}^{+}$medium arrested AP generation and produced a profound hyperpolarization of the resting membrane potential in TTX. We therefore conclude that SNr neurons express a background cationic conductance that depolarizes the neurons into the voltage range at which APs can be generated. The exact nature of this conductance is unknown, but it is carried, at least in part, by $\mathrm{Na}^{+}$ions. Candidates that may underlie the background conductance include a low-threshold TTX-insensitive $\mathrm{Na}^{+}$channel (for review, see Delmas et al., 1997) and the $\mathrm{Na}^{+} / \mathrm{Ca}^{2+}$ exchanger. In addition, the possible contribution of a tonic $\mathrm{Ca}^{2+}$ flux cannot be ruled out.

\section{SK channels are important for the precision of autonomous activity}

Intrinsically generated spontaneous activity is influenced by apamin-sensitive SK channels in several of the neuron types described above. In dopaminergic neurons of the SNc (Kang and Kitai, 1993; Sarpal et al., 2004) and thalamocortical relay neurons (McCormick and Pape, 1990), these channels activate as the cells depolarize and are responsible for the descending phase of the subthreshold oscillation. In STN neurons (Hallworth et al., 2003) and striatal cholinergic interneurons (Bennett et al., 2000), each AP is rapidly followed by a pronounced AHP, the slow component of which is mediated principally by SK channels. In these cases, $\mathrm{Ca}^{2+}$ enters the cell through "high" voltage-activated $\mathrm{Ca}^{2+}$ channels that are activated by APs (Sah, 1996; Xia et al., 1998). As in STN neurons, we found that the single-spike AHP in $\mathrm{SNr}$ GABA neurons was reduced by the application of apamin, suggesting that SK channels are also activated after APs in SNr neurons. Indeed, the activation of SK channels in both STN and $\mathrm{SNr}$ neurons was coupled, at least in part, to $\mathrm{Ca}^{2+}$ entry through $\mathrm{Ca}_{\mathrm{V}} 2.2$ channels, which are the major (high-voltage) $\mathrm{Ca}_{\mathrm{v}}$ channels in these neurons (Westenbroek et al., 1992; Song et al., 2000) and are presumably activated at suprathreshold voltages associated with APs.

Reduction of the AHP also elevated $\mathrm{AP}_{\text {th }}$ and disrupted the pace and precision of firing, which is symptomatic of a reduction in $\mathrm{Na}_{\mathrm{v}}$ channel availability. Thus, a fundamental role of the SK channels in the $\mathrm{SNr}$, and other autonomously active neurons, is to deepen and lengthen the AP AHP, which may enable $\mathrm{Na}_{\mathrm{v}}$ channels to recover from the inactivation that accumulated in the preceding $\mathrm{AP}(\mathrm{s})$.

\section{Autonomously generated APs reliably backpropagate into the dendrites of SNr GABA neurons}

Backpropagating APs have been observed in a diverse range of neuronal types (for review, see Waters et al., 2005). Our recordings revealed perfectly faithful backpropagation of autonomously generated APs into the dendrites of SNr GABA neurons. In 10 of 11 of these neurons, the APs in the dendrite were observed to always follow the respective APs in the soma, suggesting that the site of AP generation is either axonal or somatic, but 
generally not dendritic. The conduction velocity of backpropagation was also comparable with previously reported values for hippocampal CA1 neurons and neocortical pyramidal neurons (Spruston et al., 1995; Stuart et al., 1997a).

The significance of backpropagating autonomous activity for synaptic integration/plasticity in $\mathrm{SNr}$ neurons is presently unclear. It has been proposed that, when APs evoked by synaptic input backpropagate, this acts as a retrograde signal of neuronal output to the dendrites, promoting changes in the efficacy of those synapses that led to the generation of an AP (Stuart et al., 1997b; Hausser et al., 2000). In SNr neurons, the situation is complicated by the generation of APs without synaptic input. For spike-timing-dependent plasticity to operate effectively in these neurons, both autonomously and synaptically generated APs must presumably backpropagate without failure.

\section{References}

Alreja M, Aghajanian GK (1993) Opiates suppress a resting sodiumdependent inward current and activate an outward potassium current in locus coeruleus neurons. J Neurosci 13:3525-3532.

Barry PH (1994) JPCalc, a software package for calculating liquid junction potential corrections in patch-clamp, intracellular, epithelial and bilayer measurements and for correcting junction potential measurements. J Neurosci Methods 51:107-116.

Bennett BD, Callaway JC, Wilson CJ (2000) Intrinsic membrane properties underlying spontaneous tonic firing in neostriatal cholinergic interneurons. J Neurosci 20:8493-8503.

Bentivoglio M, van der Kooy D, Kuypers HG (1979) The organization of the efferent projections of the substantia nigra in the rat. A retrograde fluorescent double labeling study. Brain Res 174:1-17.

Beurrier C, Bioulac B, Hammond C (2000) Slowly inactivating sodium current (INaP) underlies single-spike activity in rat subthalamic neurons. J Neurophysiol 83:1951-1957.

Bevan MD, Wilson CJ (1999) Mechanisms underlying spontaneous oscillation and rhythmic firing in rat subthalamic neurons. J Neurosci 19:7617-7628.

Bevan MD, Bolam JP, Crossman AR (1994) Convergent synaptic input from the neostriatum and the subthalamus onto identified nigrothalamic neurons in the rat. Eur J Neurosci 6:320-334.

Bond CT, Herson PS, Strassmaier T, Hammond R, Stackman R, Maylie J, Adelman JP (2004) Small conductance $\mathrm{Ca}^{2+}$-activated $\mathrm{K}^{+}$channel knock-out mice reveal the identity of calcium-dependent afterhyperpolarization currents. J Neurosci 24:5301-5306.

Chan CS, Shigemoto R, Mercer JN, Surmeier DJ (2004) HCN2 and HCN1 channels govern the regularity of autonomous pacemaking and synaptic resetting in globus pallidus neurons. J Neurosci 24:9921-9932.

Delmas P, Raggenbass M, Gola M (1997) Low-threshold $\mathrm{Na}^{+}$currents: a new family of receptor-operated inward currents in mammalian nerve cells. Brain Res Brain Res Rev 25:246-254.

Delong MR (1990) Primate models of movement disorders of basal ganglia origin. Trends Neurosci 13:281-285.

Deniau JM, Hammond C, Riszk A, Feger J (1978) Electrophysiological properties of identified output neurons of the rat substantia nigra (pars compacta and pars reticulata): evidences for the existence of branched neurons. Exp Brain Res 32:409-422.

Deransart C, Hellwig B, Heupel-Reuter M, Leger JF, Heck D, Lucking CH (2003) Single-unit analysis of substantia nigra pars reticulata neurons in freely behaving rats with genetic absence epilepsy. Epilepsia 44:1513-1520.

Do MTH, Bean BP (2003) Subthreshold sodium currents and pacemaking of subthalamic neurons: modulation by slow inactivation. Neuron 39:109-120.

Durante P, Cardenas CG, Whittaker JA, Kitai ST, Scroggs RS (2004) Lowthreshold L-type calcium channels in rat dopamine neurons. J Neurophysiol 91:1450-1454.

Faber ES, Sah P (2002) Physiological role of calcium-activated potassium currents in the rat lateral amygdala. J Neurosci 22:1618-1628.

Feger J, Robledo P (1991) The effects of activation or inhibition of the subthalamic nucleus on the metabolic and electrophysiological activities within the pallidal complex and substantia nigra in the rat. Eur J Neurosci 3:947-952.

Gernert M, Fedrowitz M, Wlaz P, Loscher W (2004) Subregional changes in discharge rate, pattern, and drug sensitivity of putative GABAergic nigral neurons in the kindling model of epilepsy. Eur J Neurosci 20:2377-2386.

Grace AA, Bunney BS (1979) Paradoxical GABA excitation of nigral dopaminergic cells: indirect mediation through reticulata inhibitory neurons. Eur J Pharmacol 59:211-218.

Hallworth NE, Wilson CJ, Bevan MD (2003) Apamin-sensitive small conductance calcium-activated potassium channels, through their selective coupling to voltage-gated calcium channels, are critical determinants of the precision, pace, and pattern of action potential generation in rat subthalamic nucleus neurons in vitro. J Neurosci 23:7525-7542.

Harris NC, Constanti A (1995) Mechanism of block by ZD7288 of the hyperpolarization-activated inward rectifying current in guinea pig substantia nigra neurons in vitro. J Neurophysiol 74:2366-2378.

Hausser M, Stuart G, Racca C, Sakmann B (1995) Axonal initiation and active dendritic propagation of action potentials in substantia nigra neurons. Neuron 15:637-647.

Hausser M, Spruston N, Stuart GJ (2000) Diversity and dynamics of dendritic signaling. Science 290:739-744.

Jackson AC, Yao GL, Bean BP (2004) Mechanism of spontaneous firing in dorsomedial suprachiasmatic nucleus neurons. J Neurosci 24:7985-7998.

Kang Y, Kitai ST (1993) Calcium spike underlying rhythmic firing in dopaminergic neurons of the rat substantia nigra. Neurosci Res 18:195-207.

Llinas R, Yarom Y (1981a) Electrophysiology of mammalian inferior olivary neurones in vitro. Different types of voltage-dependent ionic conductances. J Physiol (Lond) 315:549-567.

Llinas R, Yarom Y (1981b) Properties and distribution of ionic conductances generating electroresponsiveness of mammalian inferior olivary neurones in vitro. J Physiol (Lond) 315:569-584.

Maccaferri G, McBain CJ (1996) The hyperpolarization-activated current (Ih) and its contribution to pacemaker activity in rat CAl hippocampal stratum oriens-alveus interneurones. J Physiol (Lond) 497:119-130.

Mailly P, Charpier S, Menetrey A, Deniau JM (2003) Three-dimensional organization of the recurrent axon collateral network of the substantia nigra pars reticulata neurons in the rat. J Neurosci 23:5247-5257.

McCormick DA, Pape HC (1990) Properties of a hyperpolarizationactivated cation current and its role in rhythmic oscillation in thalamic relay neurones. J Physiol (Lond) 431:291-318.

Mercuri NB, Bonci A, Calabresi P, Stratta F, Stefani A, Bernardi G (1994) Effects of dihydropyridine calcium antagonists on rat midbrain dopaminergic neurones. Br J Pharmacol 113:831-838.

Monteggia LM, Eisch AJ, Tang MD, Kaczmarek LK, Nestler EJ (2000) Cloning and localization of the hyperpolarization-activated cyclic nucleotidegated channel family in rat brain. Mol Brain Res 81:129-139.

Nakanishi H, Kita H, Kitai ST (1987) Intracellular study of rat substantia nigra pars reticulata neurons in an in vitro slice preparation: electrical membrane properties and response characteristics to subthalamic stimulation. Brain Res 437:45-55.

Nedergaard S (2004) $\mathrm{A} \mathrm{Ca}^{2+}$-independent slow afterhyperpolarization in substantia nigra compacta neurons. Neuroscience 125:841-852.

Nedergaard S, Flatman JA, Engberg I (1993) Nifedipine- and omegaconotoxin-sensitive $\mathrm{Ca}^{2+}$ conductances in guinea-pig substantia nigra pars compacta neurones. J Physiol (Lond) 466:727-747.

Neher E (1992) Correction of liquid junction potentials. Methods Enzymol 207:123-131.

Notomi T, Shigemoto R (2004) Immunohistochemical localization of Ih channel subunits, HCN1-4, in the rat brain. JComp Neurol 471:241-276.

Pena F, Ramirez JM (2004) Substance P-mediated modulation of pacemaker properties in the mammalian respiratory network. J Neurosci 24:7549-7556.

Pennartz CM, de Jeu MT, Bos NP, Schaap J, Geurtsen AM (2002) Diurnal modulation of pacemaker potentials and calcium current in the mammalian circadian clock. Nature 416:286-290.

Raman IM, Bean BP (1999) Ionic currents underlying spontaneous action potentials in isolated cerebellar Purkinje neurons. J Neurosci 19:1663-1674.

Raman IM, Gustafson AE, Padgett D (2000) Ionic currents and spontaneous firing in neurons isolated from the cerebellar nuclei. J Neurosci 20:9004-9016.

Richards CD, Shiroyama T, Kitai ST (1997) Electrophysiological and im- 
munocytochemical characterization of GABA and dopamine neurons in the substantia nigra of the rat. Neuroscience 80:545-557.

Sah P (1996) $\mathrm{Ca}^{2+}$-activated $\mathrm{K}^{+}$currents in neurones: types, physiological roles and modulation. Trends Neurosci 19:150-154.

Santoro B, Chen S, Lüthi A, Pavlidis P, Shumyatsky GP, Tibbs GR, Siegelbaum SA (2000) Molecular and functional heterogeneity of hyperpolarization-activated pacemaker channels in the mouse CNS. J Neurosci 20:5264-5275.

Sarpal D, Koenig JI, Adelman JP, Brady D, Prendeville LC, Shepard PD (2004) Regional distribution of SK3 mRNA-containing neurons in the adult and adolescent rat ventral midbrain and their relationship to dopamine-containing cells. Synapse 53:104-113.

Sato M, Hikosaka O (2002) Role of primate substantia nigra pars reticulata in reward-oriented saccadic eye movement. J Neurosci 22:2363-2373.

Shepard PD, Bunney BS (1991) Repetitive firing properties of putative dopamine-containing neurons in vitro: regulation by an apaminsensitive $\mathrm{Ca}^{2+}$-activated $\mathrm{K}^{+}$conductance. Exp Brain Res 86:141-150.

Song WJ, Baba Y, Otsuka T, Murakami F (2000) Characterization of $\mathrm{Ca}^{2+}$ channels in rat subthalamic nucleus neurons. J Neurophysiol 84:26302637.

Spruston N, Schiller Y, Stuart G, Sakmann B (1995) Activity-dependent action potential invasion and calcium influx into hippocampal CA1 dendrites. Science 268:297-300.

Stanford IM, Lacey MG (1996) Electrophysiological investigation of adenosine triphosphate-sensitive potassium channels in the rat substantia nigra pars reticulata. Neuroscience 74:499-509.

Stocker M, Pedarzani P (2000) Differential distribution of three $\mathrm{Ca}^{2+}$ activated $\mathrm{K}^{+}$channel subunits, SK1, SK2, and SK3, in the adult rat central nervous system. Mol Cell Neurosci 15:476-493.

Stuart G, Schiller J, Sakmann B (1997a) Action potential initiation and propagation in rat neocortical pyramidal neurons. J Physiol (Lond) 505:617-632.

Stuart G, Spruston N, Sakmann B, Hausser M (1997b) Action potential initiation and backpropagation in neurons of the mammalian CNS. Trends Neurosci 20:125-131.

Tacconi S, Carletti R, Bunnemann B, Plumpton C, Merlo Pich E, Terstappen GC (2001) Distribution of the messenger RNA for the small conductance calcium-activated potassium channel SK3 in the adult rat brain and correlation with immunoreactivity. Neuroscience 102:209-215.

Taddese A, Bean BP (2002) Subthreshold sodium current from rapidly inactivating sodium channels drives spontaneous firing of tuberomammillary neurons. Neuron 33:587-600.

Tepper JM, Martin LP, Anderson DR (1995) GABA $_{\mathrm{A}}$ receptor-mediated inhibition of rat substantia nigra dopaminergic neurons by pars reticulata projection neurons. J Neurosci 15:3092-3103.

Tseng KY, Riquelme LA, Belforte JE, Pazo JH, Murer MG (2000) Substantia nigra pars reticulata units in 6-hydroxydopamine-lesioned rats: responses to striatal D2 dopamine receptor stimulation and subthalamic lesions. Eur J Neurosci 12:247-256.

Villalobos C, Shakkottai VG, Chandy KG, Michelhaugh SK, Andrade R (2004) $\mathrm{SK}_{\mathrm{Ca}}$ channels mediate the medium but not the slow calciumactivated afterhyperpolarization in cortical neurons. J Neurosci 24:3537-3542.

Waters J, Schaefer A, Sakmann B (2005) Backpropagating action potentials in neurones: measurement, mechanisms and potential functions. Prog Biophys Mol Biol 87:145-170.

Westenbroek RE, Hell JW, Warner C, Dubel SJ, Snutch TP, Catterall WA (1992) Biochemical properties and subcellular distribution of an N-type calcium channel alpha 1 subunit. Neuron 9:1099-1115.

Wichmann T, Bergman H, Starr PA, Subramanian T, Watts RL, DeLong MR (1999) Comparison of MPTP-induced changes in spontaneous neuronal discharge in the internal pallidal segment and in the substantia nigra pars reticulata in primates. Exp Brain Res 125:397-409.

Wilcox KS, Gutnick MJ, Christoph GR (1988) Electrophysiological properties of neurons in the lateral habenula nucleus: an in vitro study. J Neurophysiol 59:212-225.

Wilson CJ (2005) The mechanism of intrinsic amplification of hyperpolarizations and spontaneous bursting in striatal cholinergic interneurons. Neuron 45:575-585.

Wilson CJ, Callaway JC (2000) Coupled oscillator model of the dopaminergic neuron of the substantia nigra. J Neurophysiol 83:3084-3100.

Wilson CJ, Weyrick A, Terman D, Hallworth NE, Bevan MD (2004) A model of reverse spike frequency adaptation and repetitive firing of subthalamic nucleus neurons. J Neurophysiol 91:1963-1980.

Windels F, Kiyatkin EA (2004) GABA, not glutamate, controls the activity of substantia nigra reticulata neurons in awake, unrestrained rats. J Neurosci 24:6751-6754.

Wolfart J, Roeper J (2002) Selective coupling of T-type calcium channels to SK potassium channels prevents intrinsic bursting in dopaminergic midbrain neurons. J Neurosci 22:3404-3413.

Wolfart J, Neuhoff H, Franz O, Roeper J (2001) Differential expression of the small-conductance, calcium-activated potassium channel SK3 is critical for pacemaker control in dopaminergic midbrain neurons. J Neurosci 21:3443-3456.

Xia XM, Fakler B, Rivard A, Wayman G, Johnson-Pais T, Keen JE, Ishii T, Hirschberg B, Bond CT, Lutsenko S, Maylie J, Adelman JP (1998) Mechanism of calcium gating in small-conductance calcium-activated potassium channels. Nature 395:503-507.

Yung WH, Hausser MA, Jack JJ (1991) Electrophysiology of dopaminergic and non-dopaminergic neurones of the guinea-pig substantia nigra pars compacta in vitro. J Physiol (Lond) 436:643-667.

Zahr NM, Martin LP, Waszczak BL (2004) Subthalamic nucleus lesions alter basal and dopamine agonist stimulated electrophysiological output from the rat basal ganglia. Synapse 54:119-128. 